\title{
Effects of environmental variability on recruitment and bioeconomic modelling in the Pacific sardine (Sardinops sagax caerulea) fishery from Magdalena Bay, Baja California Sur, Mexico
}

\author{
JUAN ANTONIO DE ANDA-MONTAÑEZ ${ }^{1}$, ALEJANDRO RAMOS-RODRÍGUEZ ${ }^{1}$ and \\ SUSANA MARTÍNEZ-AGUILAR ${ }^{2}$ \\ ${ }^{1}$ Centro de Investigaciones Biológicas del Noroeste, S.C. (CIBNOR), Mar Bermejo No. 195, Col. Playa Palo de Santa \\ Rita, La Paz, Baja California Sur 23090, México. E-mail: jdeanda@ cibnor.mx \\ ${ }^{2}$ Centro Regional de Investigación Pesquera de La Paz del INAPESCA, km 1 Carretera a Pichilingue s/n, La Paz, \\ Baja California Sur 23020, México.
}

\begin{abstract}
SUMMARY: Ricker's stock-recruitment equation, including the multivariate ENSO index (MEI) as an environmental variable, was fitted to data of the Pacific sardine (Sardinops sagax caerulea) fishery from Magdalena Bay, Baja California Sur, Mexico. The equation was then incorporated into an age-structured, bioeconomic model. Uncertainty was incorporated by using environmental fluctuations; seven-year projections, equivalent to one sardine generation, were computed. Five management options were considered in the projections: open access, effort at maximum sustainable economic yield ( $\left.\mathrm{f}_{\mathrm{MSE}}\right)$, catch at maximum sustainable yield $\left(\mathrm{C}_{\mathrm{MSY}}\right)$, equivalent effort level applied in the year $2004\left(\mathrm{f}_{2004}\right)$, and an arbitrary catch quota of 40000 tons $\left(\mathrm{CQ}_{400}\right)$. Projection results were summarised by the indicator Net Present Value (NPV) of the fishery for the modelled period. The strategies that involved some regulation in the effort level $\left(\mathrm{f}_{\mathrm{MSE}}\right.$ and $\left.\mathrm{f}_{2004}\right)$ yielded the largest NPV. On the other hand, the strategies that involved regulation of the catch predicted - in addition to a lower NPV—a substantial increase in the effort to achieve the desired catch level. This study is the first bioeconomic approach for a sardine fishery management plan in this region.
\end{abstract}

Keywords: Pacific sardine, recruitment, environment, fishery management, bioeconomic model, uncertainty.

RESUMEN: EFECTO DE LA VARIABILIDAD AMBIENTAL EN EL RECLUTAMIENTO Y MODELACIÓN BIOECONÓMICA EN LA Pesquería de SARdina del Pacífico (Sardinops sagaX CaERUlea) de Bahía Magdalena, Baja California Sur, México. La ecuación stock-reclutamiento de Ricker incorporándole el índice multivariado del ENSO (IME) como variable ambiental fue ajustada a datos de la pesquería de sardina (Sardinops sagax caerulea) de Bahía Magdalena, Baja California Sur, México. Esta ecuación fue incorporada a un modelo bioeconómico estructurado por edad. La incertidumbre fue considerada al incorporar la variabilidad ambiental, y se realizaron proyecciones de siete años de duración, que equivalen a una generación de sardina. En las proyecciones se consideraron cinco estrategias de gestión: acceso abierto, esfuerzo en máximo rendimiento económico $\left(\mathrm{f}_{\mathrm{MRE}}\right)$, captura en el máximo rendimiento sostenible $\left(\mathrm{C}_{\mathrm{MRS}}\right)$, esfuerzo igual al aplicado en el año 2004 ( $\left.\mathrm{f}_{2004}\right)$, y una cuota de captura de 40000 toneladas métricas $\left(\mathrm{CC}_{40000}\right)$. Las proyecciones fueron expresadas como el valor presente neto (VPN) de la pesquería para el período modelado. Las estrategias que involucraron alguna regulación en el nivel de esfuerzo pesquero $\left(\mathrm{f}_{\text {MRE }} \mathrm{y} \mathrm{f}_{2004}\right)$ presentaron el mayor VPN. No así las estrategias que involucraron regulación en la captura, debido a que éstas predijeron un fuerte incremento en el esfuerzo para lograr el nivel de captura deseado. Este estudio es la primera aproximación bioeconómica para la ordenación de la pesquería de sardina en esta área.

Palabras clave: sardina del Pacífico, reclutamiento, ambiente, gestión pesquera, modelación bioeconómica, incertidumbre. 


\section{INTRODUCTION}

Worldwide, the exploitation of sardine fish stocks is important not only to the food supply, but also to employment of human populations. Therefore, the manner used to control, or to limit, fishing activities is oriented toward maintaining a sustainable production of stock, preferably through a management strategy that promotes both the social and economic well-being of fishermen and the industries based on this resource (FAO, 1995). No matter what mechanism for management decision is used, it takes into consideration some assumption associated with the dynamics of the stock; for this reason, alternatives are based essentially on mathematical models that predict the possible responses of the fishery systems to the actions of management (Hilborn and Walters, 1992). Although the models utilised for this purpose have addressed biological and environmental aspects of the problem (Félix-Uraga et al., 2004; Morales-Bojórquez et al., 2003), as yet few studies have considered the biological and environmental aspects in conjunction with economics and an analysis of the risk and uncertainty of the problem (Seijo, 1986; Seijo et al., 1997a,b; Francis and Shotton, 1997; De Anda-Montañez and Seijo, 1999; Seijo et al., 2004).

The Pacific sardine (Sardinops sagax caerulea) fishery is a resource of great economic importance in the Mexican Pacific (De Anda-Montañez and Seijo, 1999; Nevárez-Martínez et al., 1999); for this reason, effort has been aimed at improving current, or designing new, management strategies that would maximise profits in the short term and assure the sustainability of the stock in the long term. The sustainability of the stock of the Pacific sardine depends to a large extent on recruitment and on the size of the stock from prior years: in this type of species, the stock is formed by various age groups produced by spawning in previous years.

For the Pacific sardine of the Magdalena Bay on the west coast of Baja California Sur (B.C.S.), Mexico (Fig. 1), a management strategy in terms of quotas for catch, harvest rate and proportional escape has not been officially implemented (Hilborn and Walters, 1992; Caddy and Mahon, 1995). Nonetheless, Nevárez-Martínez et al. (1999) suggested a harvest rate of $0.22 \mathrm{yr}^{-1}$ for the Pacific sardine of the Gulf of California.

From the beginning of the fishing industry, the catch of Pacific sardine off the west coast of the Baja

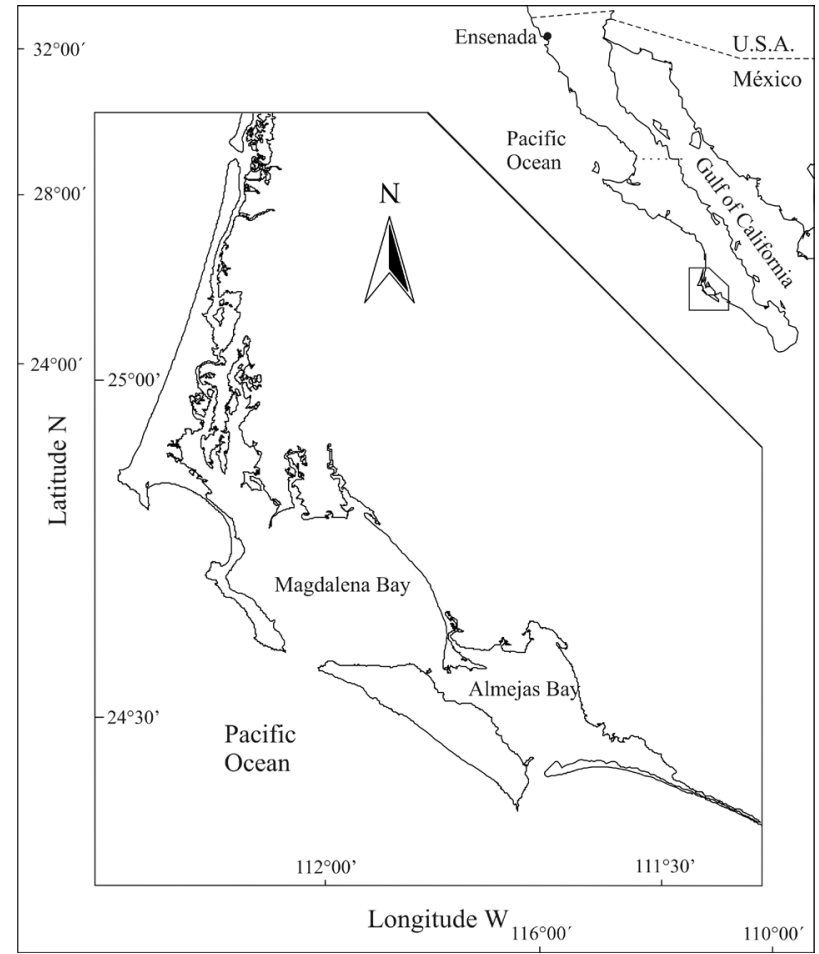

FIG. 1. - Study area of the Pacific sardine (Sardinops sagax caerulea) fishery on the western coast of the Baja California peninsula, Mexico.

California peninsula and in the Gulf of California has shown great variation that has been related to the availability of the resource. The changes in availability are attributed to the interannual fluctuations in the oceanic climate, the pattern of ocean currents, the surface temperatures of the sea, and the effects of fishing (De Anda-Montañez et al., 1994; CisnerosMata et al., 1995; De Anda-Montañez and Seijo, 1999; Félix-Uraga et al., 2004). However, the role of economic factors in the variations in catch size has not been evaluated. Thus, the objective of this study was to explore different management strategies for the Pacific sardine fishery by using a heuristic simulation model that integrated biological and economic factors and their relation to El Niño and La Niña events in the area of Magdalena Bay, Baja California Sur, Mexico.

\section{MATERIALS AND METHODS}

\section{Data sources and stock-recruitment}

The data on catch, stratified by age class, for the fishing seasons of the period from 1981 to 1993 were obtained from Félix-Uraga et al. (1996). To obtain the 
TABLE 1. - Input parameters for a bioeconomic model of the Pacific sardine fishery on the western coast of the Baja California peninsula, Mexico.

\begin{tabular}{|c|c|c|c|c|}
\hline Symbol & Description & Value & Unit of measurement & Source \\
\hline $\mathrm{W} \infty$ & Maximum weight of the V.B. equation & $86.4^{\mathrm{a}}$ & Grams & Félix-Uraga (1990) \\
\hline $\mathrm{K}$ & Curvature parameter of the V.B. equation & 0.99681 & Year $^{-1}$ & Félix-Uraga (1990) \\
\hline$t_{0}$ & Parameter of the V.B. equation & -0.01542 & Year $^{-1}$ & Félix-Uraga (1990) \\
\hline Mage & Maximum age & 7 & Years & Félix-Uraga (1986) \\
\hline $\mathrm{s}$ & Age at first reproduction & 2 & Years & Félix-Uraga (1986) \\
\hline $\mathrm{R}_{\text {initial }}$ & Initial recruitment & $1,672,727,273$ & individuals & This study \\
\hline & Density-independent coefficient & $83,250,670$ & individuals & This study \\
\hline b & Density-dependent coefficient & 0.011087 & - & This study \\
\hline c & Environmental changes parameter & -0.466698 & - & This study \\
\hline M & Natural mortality rate & 0.6 & $\overline{Y e a r}^{-1}$ & Morales-Bojórquez et al. (1999) \\
\hline $\mathrm{q}$ & Catchability & 0.000155 & Day $^{-1}$ & This study \\
\hline$\varphi$ & Fleet dynamics & 0.000246 & Year $^{-1}$ & This study \\
\hline$\stackrel{P}{P}_{p s}$ & Price of target species & 52.6 & US\$/metric tons & This study \\
\hline $\mathrm{P}_{\mathrm{os}}^{\mathrm{ps}}$ & Price of non-target species & 36.36 & US $\$ /$ metric tons & This study \\
\hline $\mathrm{Uc}^{\mathrm{os}}$ & Unit cost of effort & 2200 & US\$/fishing day & This study \\
\hline$\delta$ & Discount rate & 0.04 & Year $^{-1}$ & This study \\
\hline
\end{tabular}

a This value was obtained by converting the value reported by the author and by using the equation of non-isometric growth.

$\mathrm{a}, \mathrm{b}$ and $\mathrm{c}$ are parameters of the Ricker stock-recruitment equation.

abundance, in number of individuals, by age class per year for the period under study, the natural mortality (M) was estimated using Silliman's method (Ricker, 1975), with $\mathrm{M}=0.6 \mathrm{yr}^{-1}$ by Morales-Bojórquez (1999), and an annual rate of fishing mortality at the last age ( 6 years in our case; $\mathrm{F}_{6}=0.5 \mathrm{yr}^{-1}$ ) was fixed in the virtual population analysis (VPA) (FISAT II, version. 1.2.2, 2000-2005, FAO, Rome, Italy; http:// www.fao.org/fi/oldsite/STATIST/fisoft/fisat/index. $\mathrm{htm})$. Conversion of the number of individuals to weight by age class was performed by combining the von Bertalanffy growth equation with the weightlength relationship reported for the Pacific sardine of Magdalena Bay by Félix-Uraga (1990). For the present work, the age of recruitment was defined as one year of age and the spawning stock was formed by the individuals between the ages of two and six years (Félix-Uraga, 1990, 1992).

The parameters of Ricker's stock-recruitment equation (1954) were estimated using the LevenbergMarquardt algorithm and STATISTICA version 8.0 (StatSoft, Inc. 1984-2007, Tulsa, USA). To analyse the possible effect of environmental changes on recruitment, the multivariate index of ENSO (MEI), where ENSO is El Niño/Southern Oscillation, was obtained from the National Oceanographic and Atmospheric Administration (NOAA) of the United States (http://www.noaa.gov/) and was incorporated into the calculation. To resolve this model, multiple linear regression of the logarithmically transformed terms was used. To obtain the level of statistical significance of the parameters and the model, the $t$-test and the $F$-test were applied, respectively.

\section{Bioeconomic data set}

The data are a composite of the catch, in metric tons, and the effort, in vessel-fishing-days for the period 1983 to 2004. The information on costs and benefits was obtained by direct interview with the fishermen and the owners of the fishing fleet of the ports of San Carlos and Adolfo López Mateos in Baja California Sur. The unit price was calculated as a weighted average of the prices for packaged and processed target and non-targeted species. The parameters used in the bioeconomic model of the Pacific sardine fishery of the western coast of the Baja California peninsula, Mexico, are shown in Table 1.

\section{Mathematical model}

The dynamics of the population structure of Pacific sardine were modelled following the concepts of the method of survival of cohorts (Seijo, 1986; De Anda-Montañez and Seijo, 1999; De Anda-Montañez, 2001). The structure of the population was estimated in a dynamic form by the expression:

$$
N_{j+1, t+1}=N_{j, t} e^{-\left(M+F_{j, t}\right)}
$$

where $N_{j, t}$ is the number of individuals of age, $j$, at time, $t$ (year); $M$ is the natural mortality parameter (Morales-Bojórquez, 1999), was assumed to be constant over time and age; and $F_{j, t}$ is the fishing mortality rate, which is defined as: 


$$
F_{j, t}=f_{t} q
$$

where $f_{t}$ is the effort, in non-standardised vesselfishing-days, and $q$ is the catchability coefficient ( $q$ $=0.000155$ ) obtained by Martínez-Aguilar (2006) by using the deterministic catchability model (ArreguínSánchez, 1996); $q$ was assumed to be constant across time and age. The age at which the Pacific sardine becomes susceptible to fishing is one year.

The feedback expression (see Eq. 1 above) is given by recruitment $R_{t}$ :

$$
N_{1, t}=R_{t}
$$

where $R_{t}$ was the recruitment value estimated by the environmentally driven stock-recruitment function (Ricker, 1954). The function incorporates biotic and abiotic factors (Hilborn and Walters, 1992) that affect the recruitment of Pacific sardine over time, as follows:

$$
R_{t+1}=a S_{t} e^{-b S_{t}} e^{-c\left(M E I_{t}\right)} e^{\varepsilon}
$$

where $S_{t}$ is the spawning stock; $a$ is the densityindependent coefficient; $b$ is the density-dependent coefficient; $c$ is the coefficient that reflects the effects of environmental changes; $\mathrm{MEI}_{t}$ is the environmental variable - in this case the multivariate index of ENSO at time $t$; and $\varepsilon$ is the unexplained residual, $\varepsilon \sim N\left(0, \sigma^{2}\right)$.

The biomass was calculated by the following equation:

$$
B_{t}=\sum_{j=1}^{\text {Mage }} N_{j, t} W_{j}
$$

where Mage is the maximum age of the species (7 years) and $W_{j}$ is the individual weights of species at $j$ different ages. It was estimated using von Bertalanffy's growth equation and the corresponding length-weight relationship.

The dynamics of the fishing fleet was modelled using the function described by Smith (1969), which assumes that effort changes in proportion to profits, that is,

$$
f_{t+1}=f_{t}+\left(\varphi \pi_{t}\right)
$$

where $\varphi=0.000246$ year $^{-1}$ is the fleet dynamics parameter (if $\varphi$ is equal to zero, then effort is constant throughout time); and $\pi_{t}$ is the term for profits (net returns) at time $t$.
The yield, $Y_{j, t}$, was calculated using the standard catch equation:

$$
Y_{j, t}=\sum_{i} B_{j, t}\left(\frac{F_{j, t}}{F_{j, t}+M}\left(1-e^{-\left(F_{j, t}+M\right)}\right)\right)
$$

where $B_{j, t}$ is the biomass for age at time $t$. The ages used in calculating the total catch rate were one to six years.

The net returns at time $t$ were obtained by the expression:

$$
\pi_{t}=T R_{t}-T C_{t}
$$

where $T R_{t}$ are the total returns at time $t$ and $T C_{t}$ are the total costs at time $t$.

The total returns were estimated, starting with the price and size of the catch of target and non-targeted species, from the expression:

$$
T R_{t}=\left(P_{p s} \operatorname{Catch}_{p s, t}\right)+\left(P_{o s} \overline{\operatorname{Catch}}_{o s, t} f_{t}\right)
$$

where $P_{p s}$ is the price per ton of Pacific sardine, Catch $_{p s, t}$ is the catch of Pacific sardine per vesselfishing-day at time $t, P_{o s}$ is the price per ton of other species, and $\overline{C a t c h}_{o s, t}$ is the average catch of other species per vessel-fishing-day at time $t$.

The total costs were calculated as

$$
T C_{t}=(V C / f) f_{t}+(F C / s h) s h_{t}
$$

where $V C / f$ is the variable cost per unit of effort, $s h$ is the number of ships, $F C / s h$ is the fixed cost per ship.

Net present value $(N P V)$ is defined as

$$
N P V=\sum_{t=0}^{n} \frac{T R_{t}-T C_{t}}{(1+\delta)^{t}}
$$

where $n$ is the total span of years used in the simulation run, and $\delta$ is the discount rate (Seijo and Caddy, 2008).

\section{Model assumptions}

For the model, we made the following assumptions: 1) in the density-dependence recruitment is described by an environmentally driven stockrecruitment function; 2) the effort changes in proportion to profits; 3 ) values for natural mortality and catchability are constant and similar for all ages; 4) fishing mortality is a function of catchability and fishing effort; and 5) variable costs depend on fishing mortality rate and fixed costs depend on the invest- 
ment capital. Migration was not directly considered in the model.

\section{Model validation}

The values generated by the model were compared with observed values for the two most important variables of the system, catch and effort. The Kolmogorov-Smirnov non-parametric test was done by testing for goodness of fit of the predicted and observed distributions of catch and effort. This test is not only sensitive to differences in the means, but can also detect differences in the shape of the distribution curves. The model was run in deterministic setting, but the recruitment was estimated by the environmentally driven stock-recruitment function.

\section{Simulation of fishery management strategies}

Different management strategies were simulated to determine the effect on $N P V$. The hypothetical strategies were the following:

1) Open access (run base);

2) Effort at maximum sustainable economic yield ( $\mathrm{f}_{\mathrm{MSE}}=756$ trips) obtained from the run base in the year 2001;

3) Catch at maximum sustainable yield $\left(\mathrm{C}_{\mathrm{MSY}}=\right.$ 45800 ton) obtained from the run base in the year 2002;

4) Effort applied in 2004 ( $\mathrm{f}_{2004}=851$ trips); and

5) Catch quota (CQ) assigned as 40000 metric tons, to the values of the catch obtained in the year $2001\left(\mathrm{CQ}_{40000}\right)$.

Each of the five hypothetical strategies was implemented, starting with the 2005 season and continuing for a period of seven years.

\section{Dealing with uncertainty analysis}

In order to deal with uncertainty in the decision tables, we defined four states of nature, or hypotheses, related to environmental variability:

State 1: Run base with normal conditions (values of MEI near to zero);

State 2: Positive values of MEI predominate, "El Niño" conditions (similar period to the found in the years 1990-1995);

State 3: Negative values of MEI prevail, "La Niña" conditions (similar period to those found in the years 1973-1978); and
State 4: Cycle "El Niño-La Niña" (similar period to those found in the years 1980-1985), with normal conditions at the beginning, positive and negative in the middle, and normal at the end.

Fishery performance for each state of nature was evaluated using the five alternative management options mentioned above. In general, the decision analysis was carried out according to Seijo et al. (1997a,b), as reported in the subsequent sections.

\section{Decision analysis with mathematical probabilities}

When mathematical probabilities on the occurrence of possible performances of the fishery $\left(p_{i}\right)$ associated with the defined states of nature $\left(\right.$ State $\left._{i}\right)$ are available, which in this study referred to the possible values of MEI, it is possible to estimate the expected value $(E V)$ of the $N P V$ of the fishery resulting from use of the different management strategies $(d)$. The $E V$ was estimated as:

$$
E V_{d}=\sum_{i=1}^{n} p_{i} N P V_{d, i}
$$

and the corresponding variance (VAR) was estimated as

$$
V A R=\sum_{i=1}^{n} p_{i}\left(N P V_{d, i}-E V_{d}\right)^{2}
$$

The values of $p_{\mathrm{i}}$ of the different states of nature were obtained from the occurrence with which these environmental conditions were observed in the period from 1950 to 2004. Thus, the $E V$ and $V A R$ were evaluated for the different management strategies.

\section{Decision analysis with "Bayesian" criterion}

The Bayesian criterion is a procedure that uses prior or posterior probabilities to aid the selection of a management strategy. It was used to prompt the sardine fishery manager to select the strategy that minimises the matrix of expected loss of opportunities. Decisions without experimentation use prior distributions estimated from experiences that are translated subjectively into numerical probabilities. The decisions that are based on additional experimentation can use posterior probabilities. Posterior probabilities are the conditional probability of state of nature $i$, given the experimental data as well as the subjective prior (Seijo et al., 1997a). 


\section{Decision analysis without mathematical probabilities}

In the absence of mathematical probabilities, three decision approaches were applied to represent different degrees of caution in the selection of the management strategy (Schmid, 1989; Seijo et al., 1997a, b): 1) the Maximin criterion would be applied by a highly cautious, responsible administrator with an aversion to risk, by selecting the strategy that involves the maximum value of the observed minimum NPV; 2) the Minimax regret criterion would be applied when the administrator is cautious, but not as cautious as in the previous case, that is, the administrator would select the strategy that minimises the maximum regret, defined as the difference between the real benefit and the one that could have been obtained if the correct decision had been taken; and 3) the Maximax criterion would be applied when the administrator is broadly optimistic. The administrator would select the strategy that maximises the NPV of the different management strategies and states of nature.

\section{RESULTS}

\section{Stock-recruitment}

The relation between spawning stock and recruitment in the period 1981 to 1992 and the adjustment of the Ricker's stock-recruitment equation is shown in Figure 2. Throughout the period of the study, a great variability in recruitment was observed; that is, the largest annual classes occurred (in descending order) in 1984, 1988, 1981 and 1990, each of which had a different size of stock; the two highest values of biomass were less than 130000 metric tons. On the other hand, the annual classes of 1982, 1983, 1986, and 1991 were the weakest and each also had a different size of stock. In general, the distribution showed a density-dependent relationship: the greater size of stock tended to a lower recruitment. The statistical $t$-test and $F$-test applied to the parameters and to the model, respectively, were statistically significant to a confidence level of $1 \%(P<0.01)$.

The MEI values that describe the environmental conditions that were prevalent in the period under study are presented in Figure 3; this environmental variability represented by the MEI was incorporated into Ricker's stock-recruitment function . The result of adjusting the stock-recruitment function for the

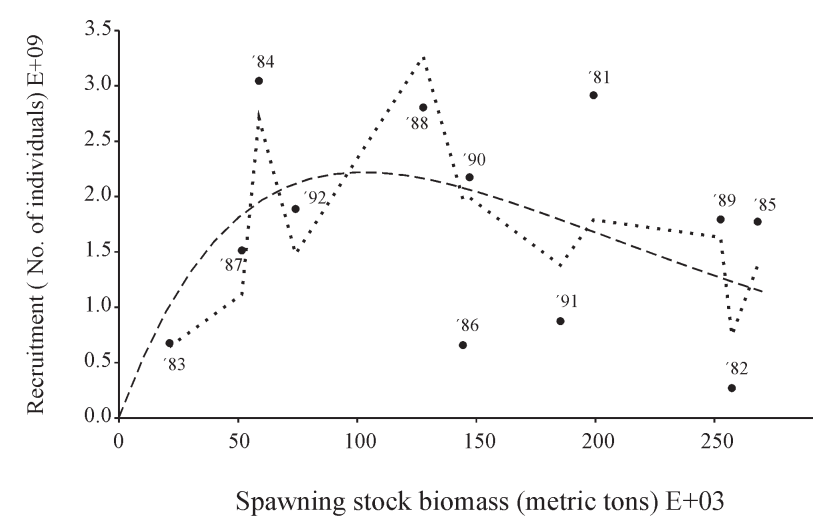

FIG. 2. - Observed recruitments and recruitments calculated by using Ricker's stock-recruitment function, with and without the environmental effect, for the population of Pacific sardine in the area of Magdalena Bay. ( ) Observed recruitment (years 1981 to 1992); (- -) calculated recruitment, $\mathrm{R}=58883473 \mathrm{~S} \mathrm{e}^{(-0.01 \mathrm{~S})} ;(\ldots)$ calculated recruitment with MEI, $\mathrm{R}=83250670 \mathrm{~S} \mathrm{e}^{(-0.011 \mathrm{~S})} \mathrm{e}^{(-0.467 \mathrm{MEI})}$.

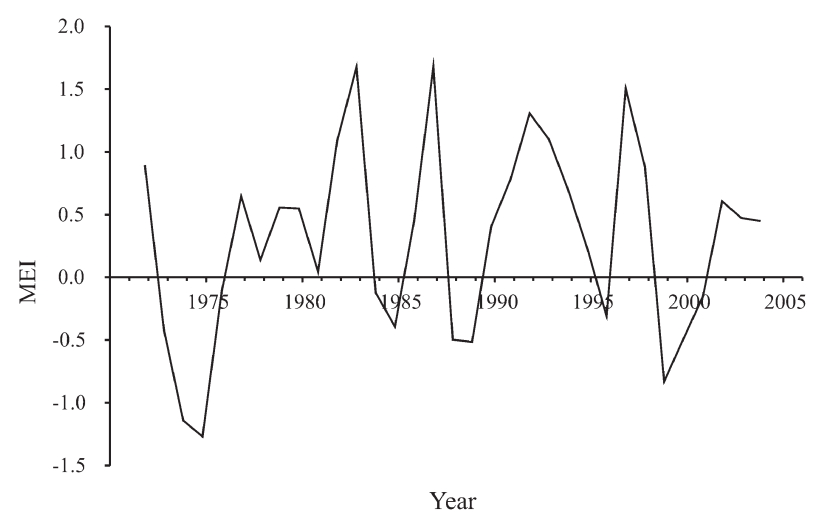

FIG. 3. - Multivariate ENSO index (MEI) in the area of Magdalena Bay for the period 1972-2004 (annual averages) (Data taken from National Oceanographic and Atmospheric Administration (NOAA) http://www.noaa.gov/).

environmental factor is shown in Figure 2. The model was statistically significant to a $1 \%$ confidence level and the parameters were also significant, two of them to a $1 \%$ and the other to a $5 \%$ confidence level. The model explained the $55 \%$ variation in the data of stock-recruitment and environment (adjusted $\mathrm{R}^{2}=0.55$ ).

The comparison between Ricker's model without taking the environmental variation into account and the model that incorporated the MEI data (Fig. 2) showed that incorporation of the environmental variation was an improvement. In general, this model indicated that there is a negative relationship between recruitment in Magdalena Bay and positive values of MEI; the recruitment was seen to be strongly influenced by the cold phase of ENSO, with recruitment being higher during the presence of La Niña. This environment-dependent stock-recruitment function was used in the bioeconomic model. 

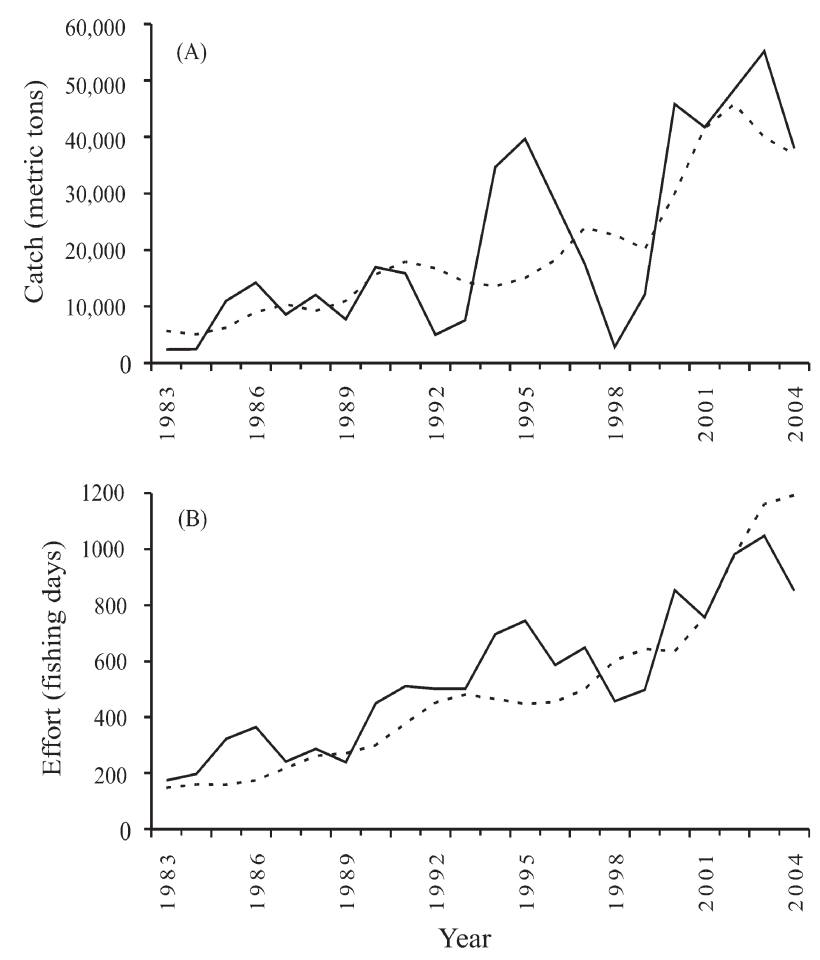

FIG. 4. - Validation of the bioeconomic model by comparing the observed and simulated values for catch and effort for fishing years 1983 to 2004 . The two variables showed no significant differences, $(P>0.39)$ and $(P>0.24)$, respectively. (A) Catch; (B) effort; $(-)$ observed values; and (- -) simulated values.

\section{Model validation}

The model outputs in catch and effort showed congruent patterns, with relatively small deviation in values from those observed (Figs. 4a and $4 b)$. In both cases, the Kolmogorov-Smirnov nonparametric statistical test showed no significant differences for catch $(P>0.10)$ or for effort $(P>0.10)$. As a consequence, we assert that the distributions of observed and simulated variables of our model were not statistically different.

\section{Decision analysis with mathematical probabilities}

Table 2 shows the different NPVs corresponding to the states of nature, defined by MEI values, and the different management strategies. This Table shows that years dominated by warm conditions (El Niño) corresponding to positive values of MEI had negative repercussions for the fishery, represented by low values in the NPV, whereas years with cold conditions (La Niña) showed substantial increases in the NPV. According to the decision criteria, a risk-neutral decision maker, that is, one who decides on the base of the EV of NPV, without taking into account the variance, would select the strategy of $\mathrm{f}_{2004}$. A risk-averse fishery manager would decide on the basis of less variance and would select the catch-quota strategy. An administrator willing to take a risk would decide on the maximum NPV, thereby selecting the open-access strategy.

\section{Decision analysis with Bayesian criterion}

Use of the Bayesian criterion with different states of nature and management options indicated that the fishery manager would select the decision that minimises the expected loss of opportunities: in this case, the strategy $\mathrm{f}_{2004}$ (Table 3).

\section{Decision analysis without mathematical probabilities}

Table $4 \mathrm{a}$ shows the results of applying the Maximin criterion. The $\mathrm{f}_{\mathrm{MSE}}$ and $\mathrm{f}_{2004}$ strategies were the two that provided the maximum value of the minima and they were the two that an extremely cautious administrator (one with

TABLE 2. - Results of the decision analysis with mathematical probabilities $\left(p_{\mathrm{i}}\right)$ considering five management strategies with four states of nature defined by MEI ${ }^{a}$ values.

\begin{tabular}{|c|c|c|c|c|c|c|}
\hline \multirow{4}{*}{ Strategy } & \multicolumn{3}{|c|}{ Net present value of the fishery (US\$) } & \multirow{4}{*}{$\begin{array}{c}\text { State } 4 \\
\text { MEI }(+,-) \\
p_{4}=0.28\end{array}$} & \multirow{4}{*}{ Expected Value } & \multirow{4}{*}{ Variance } \\
\hline & State 1 & State 2 & State 3 & & & \\
\hline & Normal & MEI (+) & MEI (-) & & & \\
\hline & $p_{1}=0.36$ & $p_{2}=0.18$ & $p_{3}=0.18$ & & & \\
\hline 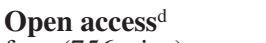 & 246608 & 35612 & 451107 & 194891 & 230958 & $1.60 \mathrm{E}+10$ \\
\hline $\mathrm{f}_{\mathrm{MSE}}(756$ trips $)$ & 222709 & 113896 & 368655 & 190902 & 220487 & $6.24 \mathrm{E}+09$ \\
\hline $\mathrm{C}_{\mathrm{MSY}}(45800$ ton $)$ & 95507 & -9650 & 78179 & 83492 & 70096 & $1.43 \mathrm{E}+09$ \\
\hline$f_{2004}\left(851\right.$ trips $^{\mathrm{b}}$ & 235841 & 113434 & 399223 & 199104 & 232930 & $7.87 \mathrm{E}+09$ \\
\hline $\mathrm{CQ}_{40000}(40000 \text { ton })^{\mathrm{c}}$ & 26437 & -44347 & 21488 & 22997 & 11842 & $6.96 \mathrm{E}+08$ \\
\hline
\end{tabular}

a MEI: multivariate ENSO index

Boldface indicates the selected management strategies according to the decision criterion ( ${ }^{b}$ risk-neutral; ${ }^{c}$ risk-averse; and ${ }^{\mathrm{d}}$ risk-seeking). 
TABLE 3. - Results of the decision analysis with use of Bayesian criterion.

\begin{tabular}{|c|c|c|c|c|c|}
\hline \multirow[b]{2}{*}{ Strategy } & \multirow[b]{2}{*}{$\begin{array}{c}\text { State 1 } \\
\text { Normal } \\
p_{1}=0.36\end{array}$} & \multicolumn{2}{|c|}{ Net present value of the fishery (\$US) } & \multirow[b]{2}{*}{$\begin{array}{c}\text { State } 4 \\
\text { MEI }(+,-) \\
p_{4}=0.28\end{array}$} & \multirow[b]{2}{*}{ Expected Value } \\
\hline & & $\begin{array}{c}\text { State } 2 \\
\text { MEI }^{\mathrm{a}}(+) \\
p_{2}=0.18\end{array}$ & $\begin{array}{c}\text { State } 3 \\
\text { MEI }(-) \\
p_{3}=0.18\end{array}$ & & \\
\hline Open access & 0 & 78284 & 0 & 4214 & 15271 \\
\hline $\mathrm{f}_{\mathrm{MSE}}(756$ trips $)$ & 23900 & 0 & 82452 & 8203 & 23445 \\
\hline $\mathrm{C}_{\mathrm{MSY}}(45800$ ton $)$ & 151101 & 123546 & 372928 & 115612 & 143762 \\
\hline$f_{2004}(851$ trips $)$ & 10767 & 462 & 51884 & 0 & 13298 \\
\hline $\mathrm{CQ}_{40000}(40000$ ton $)$ & 220171 & 158244 & 429620 & 176108 & 185077 \\
\hline
\end{tabular}

aMEI: multivariate ENSO index

Boldface indicates the selected management decision.

TABLE 4. - Results of the decision analysis without mathematical probabilities but with the use of the a) Maximin, b) Minimax, and c) Maximax criteria, considering five management strategies with four states of nature defined by MEI ${ }^{\text {a }}$ values.

\begin{tabular}{|c|c|c|c|c|c|}
\hline Strategy & $\begin{array}{l}\text { State } 1 \\
\text { Normal }\end{array}$ & $\begin{array}{l}\text { Present } \\
\text { State } 2 \\
\text { MEI (+) }\end{array}$ & $\begin{array}{l}\text { ishery (US } \\
\text { State } 3 \\
\text { MEI (-) }\end{array}$ & $\begin{array}{c}\text { State } 4 \\
\text { MEI }(+,-)\end{array}$ & \\
\hline A) Maximin Criterion & & & & & Minimum \\
\hline $\begin{array}{l}\text { Open access } \\
\mathbf{f}_{\text {MSE }} \text { (756 trips) } \\
\mathrm{C}_{\mathrm{MSY}}(45800 \text { ton }) \\
\mathbf{f}_{2004}(\mathbf{8 5 1} \text { trips }) \\
\mathrm{CQ}_{40000}(40000 \text { ton })\end{array}$ & $\begin{array}{c}246608 \\
222709 \\
95507 \\
235841 \\
26437\end{array}$ & $\begin{array}{c}35612 \\
113896 \\
-9650 \\
113434 \\
-44347\end{array}$ & $\begin{array}{c}451107 \\
368655 \\
78179 \\
399223 \\
21488\end{array}$ & $\begin{array}{l}194891 \\
190902 \\
83492 \\
199104 \\
22997\end{array}$ & $\begin{array}{c}35612 \\
\mathbf{1 1 3 8 9 6} \\
-9650 \\
\mathbf{1 1 3 4 3 4} \\
-44347\end{array}$ \\
\hline B) Minimax Criterion & & & & & $\begin{array}{c}\text { Maximum } \\
\text { (Loss of opportunities } \\
\text { matrix) }\end{array}$ \\
\hline $\begin{array}{l}\text { Open access } \\
\mathrm{f}_{\text {MSE }}(756 \text { trips }) \\
\mathrm{C}_{\text {MSY }}(45800 \text { ton }) \\
\mathbf{F}_{2004}(\mathbf{8 5 1} \text { trips }) \\
\mathrm{CQ}_{40000}(40000 \text { ton })\end{array}$ & $\begin{array}{c}0 \\
23900 \\
151101 \\
10767 \\
220171\end{array}$ & $\begin{array}{c}78284 \\
0 \\
123546 \\
462 \\
158244\end{array}$ & $\begin{array}{c}0 \\
82452 \\
372928 \\
51884 \\
429620\end{array}$ & $\begin{array}{c}4214 \\
8203 \\
115612 \\
0 \\
176108\end{array}$ & $\begin{array}{c}78284 \\
82452 \\
372928 \\
\mathbf{5 1 8 8 4} \\
429620\end{array}$ \\
\hline C) Maximax Criterion & & & & & Maximum \\
\hline $\begin{array}{l}\text { Open access } \\
\mathrm{f}_{\mathrm{MSE}}(756 \text { trip) } \\
\mathrm{C}_{\mathrm{MSY}}(45800 \text { ton }) \\
\mathrm{F}_{2004}(851 \text { trips }) \\
\mathrm{CQ}_{40000}(40000 \text { ton })\end{array}$ & $\begin{array}{c}246608 \\
222709 \\
95507 \\
235841 \\
26437\end{array}$ & $\begin{array}{l}35612 \\
113896 \\
-9650 \\
113434 \\
-44347\end{array}$ & $\begin{array}{c}451107 \\
368655 \\
78179 \\
399223 \\
21488\end{array}$ & $\begin{array}{l}194891 \\
190902 \\
83492 \\
199104 \\
22997\end{array}$ & $\begin{array}{c}\mathbf{4 5 1 1 0 7} \\
368655 \\
95507 \\
399223 \\
26437\end{array}$ \\
\hline
\end{tabular}

${ }^{\mathrm{a} M E I}$ : multivariate ENSO index

Boldface indicates the selected management decision(s) for each criterion.

risk-aversion) would select (Table 4a). The Minimax criterion would be applied by a less cautious administrator, with the best strategy choice also being $\mathrm{f}_{2004}$, the strategy that would give the minimum value between the values corresponding to the maximum losses of opportunities (Table 4b). Should the Maximax criterion be selected, the resource administrator would be broadly optimistic and look for risk. In such a case, the best strategy (Table 4c) would be the one that provides the maximum-maximum NPV of the fishery, which corresponded to open access in this study.

\section{DISCUSSION}

In the dynamics of fish populations, recruitment is an important factor because it represents the natural regulation of the size of the stock, whether or not it is subject to human exploitation; its variation is the central problem in fishery science. Such variations in recruitment and the apparent lack of a discernible periodicity in these variations make it difficult to understand, to predict, and consequently to manage fishery resources. Recruitment may be defined as the relation between the size of the spawning stock and the subsequent yearly class derived from this 
spawning (Ricker, 1954, 1975; Hilborn and Walters, 1992). The literature provides examples in which the relationship between diverse environmental factors and recruitment for different species of sardine is evident (Wada and Jacobson, 1998; Cole, 1999; Guisande et al., 2001; Yatsu et al., 2005), and in which recruitment appears to oscillate, depending on the prevailing climatic conditions. For the Pacific sardine off the west coast of the Baja California peninsula, the few studies that have been performed on stock recruitment (Morales-Bojórquez, 1999, 2002; Morales-Bojórquez et al., 2003) have shown that it is susceptible to the surface temperature of the sea in this zone. During the positive phase of an ENSO event, the Pacific sardine practically disappears, whereas during the negative phase, the 0 and 1 year age classes increase in Magdalena Bay (CasasValdez, 1987; Félix-Uraga, 1992). The results of our model also showed a negative relationship between recruitment in Magdalena Bay and positive values of MEI; the recruitment was seen to be strongly influenced by the cold phase of ENSO, with recruitment being higher during the presence of La Niña.

In response to an El Niño event, the Pacific sardine moves to the north; under temperate or cold conditions, it moves to the south (Félix-Uraga et al., 2004). In addition to the temperature, this migratory pattern follows a circulation pattern of predominant winds and currents. Thus, in warm years, the catch of Pacific sardine in Magdalena Bay tends to be excessively low, with an increase in the capture of other species of fish usually found in more tropical waters, while the catch of Pacific sardine in waters near Ensenada increases during this type of event (CasasValdez, 1987; Félix-Uraga et al., 1996; Félix-Uraga et al., 2004).

Palomares-García et al. (2003) described some alterations that occurred in Magdalena Bay during El Niño of 1997-1998. Temperature showed a drastic change, with anomalies up to $+4.4^{\circ} \mathrm{C}$ (reaching nearly $31^{\circ} \mathrm{C}$ ) in the zone. In addition, they found a reduction in the chlorophyll $\left(0.2 \mathrm{mg} / \mathrm{m}^{3}\right)$ and in the zooplankton biomass, as well as a drastic change in the specific composition of the zooplankton in the zone, and observed more species of tropical affinity than subtropical or temperate species. Their ichthyoplankton samplings showed a reduction in the Pacific sardine and the presence of species such as Opisthonema spp and Anchoa spp. The possible combinations of above-mentioned factors probably act in a synergistic manner, resulting in reduced survival of eggs and larvae and, therefore, in the recruitment of Pacific sardine a year later.

When abnormally warm conditions begin to lessen or disappear, this leads to a re-establishment of the stable conditions that normally predominate in the zone. In this case, the dominant wind pattern returns and therefore so does the surface current pattern. This implies that the Pacific sardine returns to its normal distribution pattern. This is reflected in the fluctuations in catches: the volumes begin to increase after an event of this type, although not to their usual level, perhaps due to the poor recruitment that resulted from El Niño conditions of the previous year (Casas-Valdez, 1987; Félix-Uraga, 1992).

The upwelling in a La Niña event lasts longer and is more intense, because, with the cooling, the mixing layer rises toward the surface, thereby facilitating Ekman transport even when the winds are of normal intensity (Mann and Lazier, 1991). An important effect during a La Niña event is the increased availability of food, which helps support the reproductive success of the sardine. The factors mentioned here are some of the possible causes of the increase in recruitment that is found with the Ricker equation and that is detected a year after a La Niña event occurs.

Upon incorporating the environment-dependent stock-recruitment function into our bioeconomic model, the earnings were seen to be affected by any climatic condition that had repercussions on the sardine fishery; the advection of warm waters arising from El Niño had a particular impact. In such cases, the NPV was drastically reduced. In the contrary case (La Niña), the earnings were maximised considerably, indicating the benefit that cold conditions afford the Pacific sardine in the study area. In the case of a typical El Niño-La Niña event, the NPV of the sardine fishery suffered a slight economic loss compared to "normal" conditions (values of MEI near to zero). However, such a situation could have more serious economic implications if these events are not anticipated and provisions are not made.

The probabilities used in this analysis were based on the historical series of values for MEI; they may be considered as representative of the environmental uncertainty of the area under study. Because inclusion of the MEI values had such significant environmental influences and economic repercussions on the sardine fishery, we recommend that MEI values be included in the evaluations of biomass of the sardine stock for any plan of management that may be implemented in the Magdalena Bay. 
In the majority of the cases using these decision tables (with or without mathematical probabilities), strategies were selected that involved regulation of the fishing effort, irrespective of the administrator's attitude toward risk. In the case of the analysis with mathematical probabilities, in which a risk-averse administrator would select $\mathrm{CQ}_{40000}$, it can be seen that this strategy was far from being a viable option for the fishery both due to its poor economic yield (less than 26500 dollars in all states of nature) and due to the model's prediction of a drastic increase in the effort needed to achieve the stated catch quota. In general, for the majority of the decision criteria, the strategies that regulate effort (i.e. $\mathrm{f}_{\mathrm{MSE}}$ and $\mathrm{f}_{2004}$ ) were shown to be the most viable for administration of the sardine fishery in the Bay. The model showed that the fishery was stable, operated slightly above the $\mathrm{f}_{\mathrm{MSE}}$, and was not over exploited. Based on these results, we recommend maintaining the effort used in 2004, due to the uncertainty associated with availability and abundance. Research efforts must be oriented towards improving the bioeconomic model of the Pacific sardine fishery in accordance with future observations. Of particular interest are the possibility of observing changes over time for other parameters, such as the catchability coefficient $(q)$, natural mortality $(M)$, unit cost of effort $\left(U_{c}\right)$, price of target $\left(P_{p s}\right)$ and non-target $\left(P_{o s}\right)$ species, functions such as stock-recruitment and growth, behaviour displayed by the fishing fleet in space, and distributions of sardine in space. We recommend that an information system, including a database for the fishing industry, be established to record routine biological and economic information.

\section{ACKNOWLEDGMENTS}

The authors thank the sardine producers of the ports of San Carlos and López Mateos, Baja California Sur, Mexico for supplying data for the Pacific sardine fishery of Magdalena Bay. The authors also thank Veronica Yakoleff for editing the English-language text. JAAM and SMA thank Consejo Nacional de Ciencia y Tecnología for financial support (CONACYT operating Grant 290537-IPN and 25816, respectively)

\section{REFERENCES}

Arreguín-Sánchez, F. - 1996. Catchability: a key parameter for fish stock assessment. Rev. Fish. Biol. Fish., 6: 221-242.

Caddy, J.F. and R. Mahon. - 1995. Reference points for fishery management. FAO Fish. Tech. Pap., No. 347, Rome, Italy.

Casas-Valdez, M.M. - 1987. Distribución en tiempo y espacio de las especies de sardina y macarela en Bahía Magdalena, B.C.S., México. Inv. Mar. CICIMAR., 3(2): 11-30.

Cisneros-Mata, M.A., M.O. Nevárez-Martínez and M.G. Hammann. - 1995. The rise and fall of the Pacific Sardine, Sardinops sagax caeruleus Girard, in the Gulf of California, Mexico. Rep. CCOFI., 36: 136-143.

Cole, J. - 1999. Environmental conditions, satellite imagery, and clupeoid recruitment in the northern Benguela upwelling system. Fish. Oceanogr., 8(1): 25-38.

De Anda-Montañez, J.A. - 2001. Análisis bioeconómico de la pesquería de atún aleta amarilla (Thunnus albacares) del Pacífico oriental tropical. Ph.D. thesis, UNAM.

De Anda-Montañez, J.A., J.C. Seijo and S. Martínez. - 1994. Reclutamiento y variabilidad ambiental en la pesquería de sardina monterrey (Sardinops sagax) del Golfo de California, México. Invest. Pesq. (Chile), 38: 23-36.

De Anda-Montañez, A. and J.C. Seijo. - 1999. Bioeconomics of the Pacific sardine (Sardinops sagax) fishery in the Gulf of California, México. Rep. CCOFI, 40: 170-178.

FAO. - 1995. Precautionary approach to fisheries. Part 1: Guidelines on the precautionary approach to capture fisheries and species introductions. Elaborated by the Technical Consultation on the Precautionary Approach to Capture Fisheries. FAO Fish. Tech. Pap. 350 (Part 1), Lysekil, Sweden. Rome, Italy.

Félix-Uraga, R. - 1990. Crecimiento de Sardinops sagax caerulea en Bahía Magdalena, México. Inv. Mar. CICIMAR., 5(1): 27-31.

Félix-Uraga, R. - 1992. Composición por edades de la sardina monterrey Sardinops caeruleus capturada en Bahía Magadalena B.C.S., México, de 1981 a 1991. Inv. Mar. CICIMAR., 7(1): 9-13.

Félix-Uraga, R., R.M. Alvarado-Castillo and R. Carmona-Piña. 1996. The sardine fishery along the western coast of Baja California, 1981 to 1994. Rep. CCOFI., 37: 188-193.

Félix-Uraga, R., V.M. Gómez-Muñoz, C. Quiñones-Velázquez, F.N. Melo-Barrera and W. García-Franco. - 2004. On the existence of pacific sardine groups off the west coast of Baja California and southern California. Rep.CCOFI., 45: 146-151.

Francis, R.I.C.C. and R. Shotton. - 1997. "Risk" in fisheries management: a review. Can. J. Fish. Aquat. Sci., 54: 1699-1715.

Guisande, C., J.M. Cabanas, A.R. Vergara and I. Riveiro. - 2001. Effect of climate on recruitment success of Atlantic Iberian sardine Sardina pilchardus. Mar. Ecol. Prog. Ser., 223: 243-250.

Hilborn, R. and C.J. Walters. - 1992. Quantitative fisheries stock assessment: choice, dynamics and uncertainty. Chapman and Hall, New York.

Mann, K.H. and J.R.N. Lazier. - 1991. Dynamics of marine ecosystems: Biological-physical interactions in the oceans. Blackwell Scientific Publications. Boston, Massachussets.

Martínez-Aguilar, S. - 2006. Modelo dinámico de la pesquería de sardina monterrey (Sardinops caeruleus) del Golfo de California, México. Ph.D. thesis, Centro Interdisciplinario de Ciencias Marinas, Instituto Politécnico Nacional, México.

Morales-Bojórquez, E. - 1999. Análisis del error de proceso y de observación en la estimación del reclutamiento de la sardina del pacífico, Sardinops sagax caeruleus (Girard), en la costa suroeste de la Península de Baja California, México. Cienc. Mar., 25(4): 597-608.

Morales-Bojórquez, E. - 2002. Teorema de Bayes aplicado a la estimación del rendimiento de la sardina Monterrey (Sardinops sagax caeruleus Girard) de Bahía Magdalena, Baja California Sur, México. Cienc. Mar., 28(2): 167-179.

Morales-Bojórquez, E., V.M. Gómez-Muñoz, R. Félix-Uraga and R.M. Alvarado-Castillo. - 2003. Relation between recruitment; sea surface temperature, and dependent-density mortality of the Pacific sardine (Sardinops caeruleus) off the southwest coast of the Baja California Peninsula, Mexico. Sci. Mar., 67(1): 25-32.

Nevárez-Martínez, M.O., E.A. Chávez, M.A. Cisneros-Mata and D. Lluch-Belda. - 1999. Modeling of the Pacific sardine Sardinops caeruleus fishery of the Gulf of California, Mexico. Fish. Res., 41: $273-283$.

Palomares-García, R., A. Martínez-López, R. De Silva-Dávila, R. Funes-Rodríguez, M.A. Carballido-Carranza, R. AvendañoIbarra, A. Hinojosa-Medina and G.A. López-Ibarra. - 2003. Biological effects of El Niño 1997-98 on a shallow subtropical ecosystem: Bahía Magdalena, Mexico. Geofís. Int. 42(3): 455-466. 
Ricker, W.E. - 1954. Stock and Recruitment. J. Fish. Res. Board. Can., 11(5): 559-623.

Ricker, W.E. - 1975. Computation and interpretation of biological statistics of fish populations. Bull. Fish. Res. Board Can., 191.

Schmid, A.A. - 1989. Benefit-Cost analysis: A political economy approach. Westview Press, Boulder, Colorado.

Seijo, J.C. - 1986. Comprehensive simulation model of a tropical demersal fishery: red grouper (Epinephelus morio) of the Yucatan Continental Shelf. Ph.D. thesis, Michigan State Univ.

Seijo, J.C. and J.F. Caddy. - 2008. Port location for inshore fleets affects the sustainability of coastal source-sink resources: Implications for spatial management of metapopulations. Fish. Res., 91: 336-348.

Seijo, J.C., O. Defeo and S. Salas. - 1997a. Bioeconomía pesquera Teoría, modelación y manejo. FAO Doc. Tec. Pesca 368, FAO Rome.

Seijo, J.C., E. Pérez, M. Cabrera and D. Hernández. - 1997b. Riesgo e incertidumbre en el manejo de recursos vivos: un enfoque bioeconómico precautorio. Gestión de Sistemas Oceanográficos del Pacífico Oriental. Com. Oceanogr. Interg. UNESCO. IOC/ INF-1046, 1-432.
Seijo, J.C., E.P. Pérez and J.F. Caddy. - 2004. A simple approach for dealing with dynamics and uncertainty in fisheries with heterogeneous resource and effort distribution. Mar. Freshw. Res., 55: 249-256.

Smith, V.L. - 1969. On models of commercial fisheries. J. Polit. Econ., 77: 181-198.

StatSoft, Inc. - 2007. STATISTICA (data analysis software system), version 8.0. http://www.statsoft.com.

Wada, T. and L.D. Jacobson. - 1998. Regimes and stock-recruitment relationships in Japanese sardine (Sardinops melanosticus), 1951-1995. Can. J. Fish. Aquat. Sci., 55: 2455-2463.

Yatsu, A., T. Watanabe, M. Ishida, H. Sugisaki and L.D. Jacobson. - 2005. Environmental effects on recruitment and productivity of Japanese sardine Sardinops melanostictus and chub mackerel Scomber japonicus with recommendations for management. Fish. Oceanogr., 14(4): 263-278.

Scient. ed.: F. Maynou.

Received November 6, 2008. Accepted February 26, 2009.

Published online November 16, 2009. 